\title{
Charles Tilly as a Theorist of Nationalism
}

\author{
Rogers Brubaker
}

Published online: 28 August 2010

(C) The Author(s) 2010. This article is published with open access at Springerlink.com

\begin{abstract}
This paper considers Charles Tilly as an important but underappreciated theorist of nationalism. Tilly's theory of nationalism emerged from the "bellicist" strand of his earlier work on state-formation and later incorporated a concern with performance, stories, and cultural modeling. Yet despite the turn to culture in Tilly's later work, his theory of nationalism remained state-centered, materialist, and instrumentalist - a source of both its power and its limitations.
\end{abstract}

Keywords Nationalism $\cdot$ State $\cdot$ Nation-state

At an SSRC conference honoring Charles Tilly shortly after his untimely death, Viviana Zelizer (2008) talked about two lesser known Tillys: Chuck the cultural analyst, and Chuck the feminist analyst. ${ }^{1}$ In this spirit, I want to discuss Chuck as a theorist of nationalism. This is an unfamiliar rubric under which to consider Chuck's work, but an appropriate one. Chuck made a significant contribution to the study of nationalism, yet that contribution remains less well known than it should be. I seek here to explain that contribution and to honor Chuck as I believe he would have liked to be honored: through a critical engagement with his theory of nationalism.

Chuck was long uninterested in nations and nationalism. This was not just a matter of his being interested in other things; it was a specific and theoretically justified lack of interest. Chuck's work on state formation developed in critical reaction to the "nation-building" literature of the 1960s. He sought to escape from the problematic assumptions encoded in the teleological idea of nation-building and in the term "nation" itself-a term he described as "one of the most puzzling and tendentious items in the political lexicon" (1975: 6). He therefore deliberately shifted the focus of analysis from nation to state. The state was the primary reality; "nation" was a mystification. The adjective "national" appears throughout Chuck's work on state-formation. But it is strictly a term of scale and scope, meaning "statewide." It has no cultural content, no connection with understandings, representations, or political imagination.

\footnotetext{
${ }^{1}$ A revised version of Zelizer's paper appears as the epilogue to this special issue.

R. Brubaker $(\bowtie)$

Department of Sociology, University of California, Los Angeles (UCLA), Los Angeles, CA, USA

e-mail: brubaker@soc.ucla.edu
} 
Beginning with a 1991 article introducing a special issue of Theory and Society on ethnic conflict and nationalist movements in what was then still the Soviet Union, Chuck came to develop an interest in nationalism. The theory emerged as an extension of his work on state-formation. A key strand of that work-the bellicist strand, as Gorski (2003:5) has called it - centered on the connection between warmaking and state-making. The heightened extractive appetites of militarily expansive states caused a progressive shift from indirect to direct rule, and this in turn generated resistance from previously insulated and autonomous regional powerholders and intermediaries.

Chuck identified two forms of nationalism that emerged from this juncture of increasingly intrusive direct rule and resistance to this novel form of rule: the topdown, nation-shaping nationalism of central rulers, and the bottom-up, state-seeking nationalism of threatened peripheral elites. He defined top-down nationalism as the "insistence that the nation's collective interest, as interpreted by the state's current rulers, should take priority over all particularisms." He noted that rulers elaborated a variety of "doctrines and practices that implemented their visions of the Nation," including standardized languages, histories, ceremonies, museums, and schools (1996: 303-4). Bottom up nationalism, too, was an elite-led phenomenon (and hence the label is something of a misnomer). It was driven by political entrepreneurs who had "strong investments in alternative definitions of language, history, and community" and who responded to top-down nationalism by "rally[ing] supporters in the name of oppressed and threatened nations" (1996:304).

Chuck's first sketch of a theory of nationalism explicitly located his account "in the tradition of structural rather than cultural... or social-psychological theories" (1991: 574). In later formulations, the core of the argument remained structural, but Chuck elaborated a complementary cultural line of analysis, focused on what I would call the performative dimension of nationalism. Leaders of state-seeking nationalist movements, he observed, "put much of their energy into organizing public performances that broadcast the message: We Are a Nation" (1996: 304-5). Similar performances, one might add, are often undertaken by rulers of newly independent states.

These performances were examples of what Chuck would later call "standard stories" (2002), similar in form and content across a wide range of cases, stories that characteristically emphasized the antiquity, cultural homogeneity, and cohesiveness of the nation. As such "we are a Nation" performances gained prominence, other kinds of performances - Chuck mentions "we are the rightful dynasty" performancesbecame less relevant to establishing a rightful claim to rule (1996:305).

Performative enactments of nationhood were high-stakes performances. As external recognition became crucial to the process of establishing and validating new states, performances of nationhood- "disciplined, stereotyped public demonstrations of nationness" (1998: 179)—became increasingly important. Success in convincing key audiences of the claim to nationhood could be rewarded with control of a newly independent state.

By treating nationhood as a political claim rather than a cultural or demographic fact, by emphasizing the performative enactment of claims to nationhood, and by highlighting the importance of recognition by powerful external audiences, Chuck situated nationalism in the broader domain of social movements and contentious 
politics. His later accounts of social movements and contentious politics highlighted their identitarian and performative dimension, the ways in which they "not only ... make specific claims on power-holders, but also act out statements of the type We are Alpha, We speak for Beta, or We insist on being recognized as Gamma" (2002: 12). Linking nationalism to social movements and seeing both as forms of contentious politics illustrates Chuck's characteristic and fruitful habit of always striving to locate the phenomenon of immediate interest as an instance of a broader and more general class of phenomena, and seeking to identify similar mechanisms, processes, and properties underlying a wide range of seemingly disparate phenomena.

Another cultural element in Chuck's later formulations focused on cultural modeling, or what he called emulation (1998:174). This was an important theme or "mechanism"- though the appropriateness of mechanismal imagery may be debatable - in much of Chuck's later work. Like Benedict Anderson (1991), who emphasized the "modularity" of nationalism, Chuck emphasized the "visible, prestigious, transferable models" created by successful nationalisms, both state-led and state-seeking (1998:180). The result - and here Chuck's theory converges with new institutionalist accounts of organizational isomorphism and the cultural dimensions of the "world polity" (Meyer 1987)—was a world in which "administrative structures, constitutions, and declared commitments of regimes to development, stability, and democracy came to resemble each other far more than did the diversity of their populations, material conditions, and actual accomplishments" (1998:180).

Chuck's theory of nationalism is elegant and parsimonious. It connects his earlier work on the historical sociology of state formation with his later more general theoretical interests and ambitions. And it interestingly illustrates the way in which he sought to incorporate discourse, representation, stories, and performance into his theories in response to culturalist and constructivist challenges to "structural realism" (Tilly 2002: Chapter 1). I could go on and list other virtues of Chuck's theory. But it would be a poor sort of homage indeed to abstain from critical engagement with the theory. Chuck thrived on critical exchange. He was a brilliant critic, and he expected and demanded criticism of his own work in return (McAdam 2008). So I will sketch here a few lines of criticism.

Despite Chuck's turn towards culture, his account of nationalism remained statecentered, materialist, and instrumentalist. The cultural elements in his accountperformances, representations, and emulation-were subordinated to an underlying structural logic. That logic turned on the changing incentives created by the development of the modern state (or by state collapse or reconfiguration). Resourceintensive warfare gave central rulers incentives to develop more intensive and direct forms of rule. But the development of an increasingly powerful and intrusive state threatened regional power-holders or cultural brokers and gave them incentives to demand a state of their own. For in a world of increasingly powerful and directly ruling states, "those who control the state apparatus enjoy enormous advantages of power and wealth over those who do not" (1991:575).

These changing incentives do a good job explaining why regional elites, cultural brokers, and others whose power and position are threatened by increasingly direct and centralized forms of rule (or by some other change in the political environment) 
make claims for an independent state or autonomous polity, and why such claims often come in bunches. They also do a good job explaining why increasingly resource-hungry central rulers seek to engage those over whom they rule as citizens rather than as mere subjects, and to elicit their loyalty, identification and commitment, and not simply their compliance. But changing incentives don't explain why the claims-making of threatened elites takes the form of speaking in the name of a "nation," or why resource-hungry rulers themselves begin to use the language of nationhood to frame their claims on resources and loyalties. Nor do they explain why such claims-making elicited broad popular support (when it did elicit broad popular support, which was not always the case).

Why did central rulers and those threatened by increasingly direct rule claim to speak and act in the name of a nation? Why did they adopt the political and cultural language of nationhood, and associated rituals and practices, rather than some other political and cultural language? Why did they cultivate this particular kind of imagined community? Chuck's answer was that this language and the associated rituals and practices were useful both to centralizing rulers and to those who were resisting their initiatives (1996: 303-4). But why were they useful? Why did they help rulers to implement direct rule and extract more resources, and why did they help elites who were threatened by such increasingly direct rule and intensified extractive efforts to mobilize resistance against these changes? Why were the language of nationhood and the associated rituals and practices more effective for these purposes than other languages, rituals, and practices?

Chuck's account here is rather sketchy, but I think it goes something like this. Resource-hungry rulers, as well as those resisting projects of direct rule, benefit from subjects or followers who are not only compliant but committed; and the language of nationhood-along with associated rituals and an array of standardizing, homogenizing practices - helps produce such commitment.

But what is it about the rhetoric and rituals of nationhood that is especially apt to produce such commitment? The bellicist argument is a demand-side argument, not a supply-side argument. It explains the increased demand for commitment (as distinguished from mere compliance) at a particular historical juncture; but it doesn't explain, as it were, the supply of commitment. It doesn't explain how commitment was generated, or why specifically nationalist languages, imaginings, rituals, and practices were more effective than others in producing such commitment. Identification with and commitment to a political community have been generated in various ways in differing historical contexts; the bellicist argument can't explain why nationalism is a particularly effective mode of political socialization.

But there is a deeper problem with Chuck's emphasis on the usefulness of the rhetoric and rituals of nationhood in particular political contexts. Chuck helpfully points to the political work done by particular forms of language in particular circumstances. But his emphasis on the instrumental usefulness of nationalist rhetoric and rituals is also somewhat reductionist. I use this loaded term somewhat reluctantly. Reductionism has a bad name, but I don't think it's necessarily such a bad thing. One could argue that Chuck was a powerful theorist precisely because he was in some sense a reductionist. Theoretical power depends on parsimony; and "parsimonious" is arguably just a non-pejorative word for "reductionist." 
Of course, Chuck's passionate pursuit of parsimony stood in chronic tension with his equally passionate engagement with the superabundant richness and sheer exuberant variety of the empirical world, historical and contemporary. This dynamic - and I would say unruly - tension was part of what made his work so appealing, even to those otherwise quite allergic to reductionism.

But I digress. Parsimony has its price. In focusing on the instrumental usefulness of the language of nationhood to elite participants in struggles over extraction and power - central rulers on the one hand and peripheral elites or cultural brokers on the other-Chuck did not ask other questions about that language.

He did not ask about what made the language of nationhood plausible, resonant, meaningful, or inspiring to ordinary people - or indeed if and when it was plausible, resonant, meaningful, or inspiring to them. He did not ask how people who belonged to particular states came to understand themselves as belonging also, or indeed primarily, to particular nations. He did not ask how ordinary people came to identify with and commit themselves to elite-led national movements.

An instrumental account, built on material incentives, goes much further in explaining state-seeking nationalist claims-making by elites than in explaining popular support for such claims. For understanding the shifting self-understandings, identifications, loyalties, and commitments of ordinary people in response to stateled or state-seeking nationalist projects, Chuck's emphasis on the instrumental usefulness of nationalist rhetoric is not all that instrumentally useful.

Chuck rightly emphasized the enormous advantages of controlling a state of one's own in an age of expanding state power. But to whom do those advantages accrue? Nationalists would have us believe that they accrue to "the nation" as a whole. Chuck was in general skeptical - and I think rightly so-about nationalist rhetoric. He noted that the claims of nationalist movements, like those of social movements, "always include a measure of mystification" (1998: 178), in that they tend to exaggerate the unity and coherence of their putative constituencies as well as their own claim to represent and speak for those constituencies.

But I don't think Chuck pushed his skepticism towards nationalist rhetoric far enough. Nationalist rhetoric turns on a metaphor of ownership: every nation should have "its own" state. But that metaphor-to use Chuck's term-frequently involves a mystification. States may "belong" in theory to the nations for whom they are named; but they often belong in practice to a much narrower set of people.

Those who stand to participate in or benefit from control of an independent state have powerful incentives indeed to seek to establish such a state. But for ordinary people, the material incentives are mixed at best. Independent statehood entails a pervasive shift in the scale of political, social, and economic organization. Those who will occupy the corridors of power or fill the public sector jobs in the new state stand to benefit substantially from the downward shift in scale; but others may be harmed by the constriction of fields of production, mobility, and exchange.

I don't think Chuck paid enough attention to these mixed incentives. Although he doesn't say so directly, various formulations suggest that all members of "the nation" will benefit from the establishment of an independent state, and that popular support for independence reflects the same calculus of incentives that accounts for elite claims-making. He doesn't consider two alternative possibilities: first, that there may be minimal or limited popular support for state-seeking nationalist movements; or 
second, that support for such movements may be driven by ideal or symbolic rather than material interests, by issues of dignity and recognition rather than redistribution.

Chuck's instrumentalist, incentives-based account goes further in explaining eliteclaims-making, but it has its limits even in this domain. The prospect of controlling a state apparatus, or sharing in the spoils of such control, is indeed a powerful incentive; and if claiming to speak in the name of a nation-and organizing convincing "we are a nation" performances - is the only way to secure such control, then deploying nationalist rhetoric and organizing nationalist rituals can do useful political work for elites. But what makes that political work actually "work"? What are the conditions of its efficacy?

Such political work is likely to work when two conditions are met: first, when nationhood is widely accepted by powerful states and institutionalized in powerful organizations as the sole legitimator of independent statehood; and second, when nationhood is widely available to and internalized by ordinary people as a basic "principle of vision and division of the world," in Bourdieu's terms. The bellicistand deeply materialist and instrumentalist - story line about the shift from indirect to direct rule and the consequent change in incentives can't explain these large scale cultural transformations.

Chuck did give a cultural twist to his theory of nationalism in later formulations. But this remained largely confined to the performative, recognition-seeking dimension of nationalist claims-making; and the efficacy of these recognition-seeking performances presupposes larger cultural transformations that Chuck's theory does not address. In other words, Chuck's theory takes for granted the wide availability and powerful legitimacy of the category "nation" as a major principle of vision and division of the social world. It therefore risks explaining one aspect of nationalism by another aspect of nationalism - explaining nationalist claims-making by the preexisting availability and legitimacy of nationhood as a resonant and legitimate cultural and political category. Put another way, Chuck offers a theory of nationalism without nationhood. The theory addresses the political form of nationalist claims-making while ignoring the cultural content of nationalist sense-making.

Yet this limitation should perhaps be understood as a virtue. The term "nationalism" designates a notoriously multifaceted and protean field of phenomena. As a result, no single comprehensive theory of nationalism is possible. Chuck provided a remarkably succinct and powerful structural account of the ways in which the changing dynamics of war-making and state-making shape new kinds of claimsmaking by central rulers and threatened peripheral elites. This is not the whole story of nationalism, but it is a key strand in a complex and multi-stranded story. And Chuck formulated the causal logic of this strand more clearly and powerfully than anyone else. For this alone, he should be more widely recognized as an important theorist of nationalism. His account of nationalist performances, too, usefully situated nationalism in the wider field of social movements and contentious politics.

Chuck was once the respondent to an after-dinner talk I gave on ways of rethinking nationhood. He characterized my remarks, fairly enough, as "a bridge halfway." Warming to the metaphor, Chuck observed that "anyone venturing out very far along [this bridge] runs the risk of plunging into new confusions," and indeed - pushing the metaphor still further, as Chuck liked to do-risks "drowning" in those "murky waters" (1994:15). 
Sixteen years later, I'm still alive and kicking - if only in a struggle to stay afloat in those still-murky waters. Or maybe I'm still perched precariously on that halfbuilt bridge. In the end, the problem is not that the bridge is incomplete, or that the waters are murky: most of us, most of the time, labor on one half-built bridge or another, or struggle to find our way in murky waters. The problem is that it's a whole lot lonelier and more confusing being there without having Chuck on the opposite bank, a powerful beacon of hope and encouragement, always ready to throw a line or lend a hand.

Open Access This article is distributed under the terms of the Creative Commons Attribution Noncommercial License which permits any noncommercial use, distribution, and reproduction in any medium, provided the original author(s) and source are credited.

\section{References}

Anderson, B. (1991). Imagined communities: Reflections on the origin and spread of nationalism. London: Verso.

Gorski, P. S. (2003). The disciplinary revolution: Calvinism and the rise of the state in early modern Europe. Chicago: The University of Chicago Press.

McAdam, D. (2008). Chuck Tilly, conversationalist extraordinaire. Sociologie et Sociétés, 41(2), 15-19, pre-publication pdf at: http://essays.ssrc.org/tilly/wp-content/uploads/2009/02/homage-mcadam.pdf.

Meyer, J. W. (1987). The world polity and the authority of the nation-state. In G. M. Thomas, J. W. Meyer, \& F. O. Ramirez (Eds.), Institutional structure: Constituting state, society, and the individual. Newbury Park: Sage.

Tilly, C. (1975). Reflections on the history of European state-making. In C. Tilly (Ed.), The formation of national states in western Europe. Princeton: Princeton University Press.

Tilly, C. (1991). Ethnic conflict in the Soviet Union. Theory and Society, 20, 569-580.

Tilly, C. (1994). A bridge halfway: responding to Brubaker. Contention: Debates in Society, Culture, and Science, 4, 15-19.

Tilly, C. (1996). The state of nationalism. Critical Review, 10, 299-306.

Tilly, C. (1998). Durable inequality. Berkeley: University of California Press.

Tilly, C. (2002). Stories, identities, and political change. Lanham: Rowman \& Littlefield.

Zelizer, V. (2008). Chuck Tilly and Mozart. The Social Science Research Council, Contention, Change, and Explanation: A Conference in Honor of Charles Tilly. http://www.ssrc.org/hirschman/content/ 2008/texts/Zelizer.pdf. 